
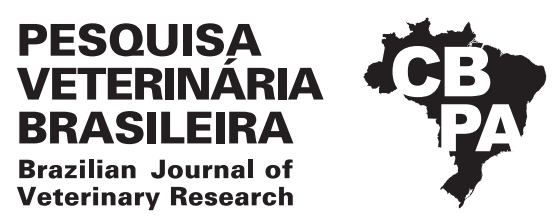

Pesq. Vet. Bras. 39(4):271-277, April 2019 DOI: 10.1590/1678-5150-PVB-5847

ISSN 0100-736X (Print)

ISSN 1678-5150 (Online)

\title{
Comparison between total intravenous anesthesia with propofol and intermittent bolus of tiletamine-zolazepam in capuchin monkey (Sapajus apella) ${ }^{1}$
}

\author{
Rafaela Galante ${ }^{2}$, Elizabeth Regina Carvalho ${ }^{2 *}$ (D), José A.P.C. Muniz ${ }^{3}$, \\ Paulo H.G. Castro ${ }^{3}$, Vanessa Nadine Gris ${ }^{2}$, Dorli S. Amora Júnior ${ }^{2}$ \\ and Ricardo G. D’Otaviano C. Vilani ${ }^{2}$
}

Original Article

Wildlife Medicine

(c) BY-NC

\begin{abstract}
Galante R., Carvalho E.R., Muniz J.A.P.C., Castro P.H.G., Gris V.N., Amora Júnior D.S. \& Vilani R.G.D'O.C. 2019. Comparison between total intravenous anesthesia with propofol or intermittent bolus of tiletamine-zolazepam in capuchin monkey (Sapajus apella). Pesquisa Veterinária Brasileira 39(4)271-277. Centro Nacional de Primatas, Evandro Chagas Instituto, Ministério da Saúde, Rodovia BR-316 Km 7, Ananindeua, PA 67030-000, Brazil. E-mail: beth_rcarvalho@hotmail.com

Dissociative anesthesia results in stressful and long recovery periods in monkeys and use of injectable anesthetics in medical research has to be refined. Propofol has promoted more pleasure wake up from anesthesia. The objectives of this study were to investigate the use of intravenous anesthetic propofol, establishing the required infusion rate to maintain surgical anesthetic level and comparing it to tiletamine-zolazepam anesthesia in Sapajus apella. Eight healthy capuchin monkeys, premedicated with midazolam and meperidine, were anesthetized with propofol (PRO) or tiletamine-zolazepam (TZ) during 60 minutes. Propofol was infused continually and rate was titrated to effect and tiletamine-zolazepam was given at $5 \mathrm{mg} / \mathrm{kg} \mathrm{IV}$ bolus initially and repeated at $2.5 \mathrm{mg} / \mathrm{kg}$ IV bolus as required. Cardiopulmonary parameters, arterial blood gases, cortisol, lactate and quality and times to recovery were determined. Recovery quality was superior in PRO. Ventral recumbency (PRO $=43.0 \pm 21.4$ vs TZ $=219.3 \pm 139.7 \mathrm{~min}$ ) and normal ambulation (PRO $=93 \pm 27.1$ vs TZ $=493.7 \pm 47.8 \mathrm{~min})$ were faster in $\mathrm{PRO}(\mathrm{p}<0.05)$. Cardiopulmonary effects did not have marked differences between groups. Median for induction doses of propofol was $5.9 \mathrm{mg} / \mathrm{kg}$, varying from 4.7 to $6.7 \mathrm{mg} / \mathrm{kg}$, Mean infusion rate was $0.37 \pm 0.11 \mathrm{mg} / \mathrm{kg} / \mathrm{min}$, varying during the one-hour period. In TZ, two animals required three and five extra doses. Compared to tiletamine-zolazepam, minor post-anesthetic adverse events should be expected with propofol anesthesia due to the faster and superior anesthetic recovery.
\end{abstract}

INDEX TERMS: Intravenous anesthesia, propofol, intermittent bolus, tiletamine-zolazepam, capuchin monkey, Sapajus paella, recovery, refinement, primate, TIVA, clinics.

RESUMO.- [Comparação entre anestesia total intravenosa com propofol e bolus intermitente de tiletamina-zolazepam em macaco-prego (Sapajus apella).] A anestesia dissociativa em primatas resulta em recuperação anestésica lenta e estressante, e, portanto, o uso de anestesia injetável em

\footnotetext{
${ }^{1}$ Received on October 15, 2018.

Accepted for publication on November 27, 2018.

${ }^{2}$ Centro Nacional de Primatas, Evandro Chagas Instituto, Ministério da Saúde, Rodovia BR-316 Km 7, Ananindeua, PA 67030-000, Brazil. *Corresponding author: beth_rcarvalho@hotmail.com

${ }^{3}$ Laboratório de Anestesia e Analgesia Veterinária, Departamento de Medicina Veterinária, Universidade Federal do Paraná (UFPR), Rua dos Funcionários 1540, Juvevê, Curitiba, PR 80035-050, Brazil.
}

pesquisas médicas precisa ser refinado. Por outro lado, o propofol promove recuperação mais suave. Os objetivos desse estudo foram investigar o uso do anestésico intravenoso propofol, estabelecer a taxa de infusão contínua necessária para manter anestesia cirúrgica, e comparar tal técnica com a dissociativa tiletamina-zolazepam em Sapajus apella. Oito macacos-prego saudáveis foram pré-medicados com midazolam e meperidina, e posteriormente anestesiados com propofol (PRO) ou tiletamina-zolazepam (TZ) durante 60 minutos. 0 propofol foi administrado em infusão contínua, e a taxa foi titulada ao efeito, já a tiletamina-zolazepam foi administrada em $5 \mathrm{mg} / \mathrm{kg}$ IV como bolus inicial, e repiques de $2,5 \mathrm{mg} / \mathrm{kg}$ IV conforme necessário. Os parâmetros 
cardiopulmonares, hemogasometria arterial, cortisol, e lactato, além da qualidade e duração da recuperação anestésica foram determinados. A qualidade da recuperação anestésica foi superior em PRO. 0 tempo para atingir decúbito ventral (PRO = 43,0 $\pm 21,4$ vs TZ = 219,3 $\pm 139,7 \mathrm{~min}$ ) e ambulação normal (PRO = 93 $\pm 27,1$ vs TZ = 493,7 $\pm 47,8 \mathrm{~min}$ ) foram mais rápidos em PRO $(p<0,05)$. As variáveis cardiopulmonares não diferiram entre os grupos. A mediana para dose de indução com propofol foi de $5,9 \mathrm{mg} / \mathrm{kg}$, variando de 4,7 a $6,7 \mathrm{mg} / \mathrm{kg}$. A taxa de infusão contínua média de propofol foi de $0,37 \pm 0,11 \mathrm{mg} / \mathrm{kg} / \mathrm{min}$, variando ao longo dos 60 minutos. Em TZ, dois animais necessitaram de três e cinco repiques. Comparado à tiletamina-zolazepam, menos efeitos adversos pós-anestésicos devem ser esperados com o propofol, devido à recuperação mais suave e rápida.

TERMOS DE INDEXAÇÃO: Anestesia total intravenosa, propofol, bolus intermitente, tiletamina-zolazepam, macaco-prego, Sapajus apela, recuperação, refinamento, primata, TIVA, clínica.

\section{INTRODUCTION}

Capuchin monkeys (Sapajus apella) are important nonhuman primates for biomedical research and the best neotropical primates at adapting to captivity (Domingues et al. 2003). Anesthesia for clinical and surgical procedures in captive primates is often required in zoos and research centers. The most common and widely established injectable protocols involve the use of dissociative agents (Olberg 2007, Vilani 2009). However, dissociative anesthesia presents long anesthetic recoveries after extended procedures, mainly when surgical anesthesia is required. Such recoveries are problematic when handling social species that require quick reintegration into the group (Galante et al. 2014) and a refinement of protocol is essential, minimizing stressful recuperation of anesthesia, once medical research is required.

We have recently described a shorter and smoother anesthetic recovery of a total intravenous anesthesia (TIVA) with continuous infusion of propofol in feline night monkeys (Galante et al. 2014). TIVA involves induction and maintenance of the anesthetic plan using only intravenous drugs (Camu et al. 2001). Propofol (2,6-diisopropylphenol) is one of the most advantageous drugs for this due to its rapid induction (Bufalari et al. 1995) and recovery (Smith et al. 1994, Ganem et al. 2002) without compromising the anesthetic plan. The rapid recovery occurs even in cases of prolonged administrations due to its rapid metabolization by the liver and also by other metabolic sites, especially the lungs, but also observed in kidney, intestine and brain (Matot et al. 1993, Court et al. 2001). The most common side effects are dose-dependent hypotension and ventilatory depression (Kotani et al. 2008, Paula et al. 2012).

The purpose of this research is to investigate the required infusion rate of propofol to maintain a surgical anesthetic level and compare this protocol to the dissociative tiletamine-zolazepam anesthesia, evaluating alterations in physiological parameters, recovery time and quality of anesthesia in capuchin monkeys.

\section{MATERIALS AND METHODS}

Capuchin monkeys (Sapajus apella) were captive born and belonged to the National Primate Center (CENP) breeding colony, located in the Municipality of Ananindeua, state of Pará, Brazil (latitude 1038'26" and longitude 48038'22"). Eight specimens were used, four males and four females, with ages from four to 16 years. The monkeys were maintained in groups of four to six animals in indoor facilities of $3 \times 5 \times 2.5 \mathrm{~m}$ accredited by the Governmental Institute of Environment and Natural Resources. Animal housing included a natural light and dark cycle, untreated water ad libitum via automatic valves and feeding of fresh fruits and vegetables and commercial pelleted feed (FOXY Junior Supreme, 28\% protein; PROVIMI, São José dos Pinhais, Brazil). The room temperature was $24-300 \mathrm{C}$ in a humid tropical climate.

At the day of experiment, the monkeys were captured with hand nets, and immediately premedicated. Food, but not water, was withdrawn six hours before the experiment. Temperature of the experimental laboratory was controlled, ranging between 25 and $26^{\circ} \mathrm{C}$. During anesthesia recovery, the specimens were housed in a $0.9 \times 0.8 \times 0.8 \mathrm{~m}$ aluminum cage until normal ambulation, returning to original facilities at the same day. This study was conducted in accordance with the Brazilian National Council for Control of Animal Experimentation guidelines and approved by the Animal Use Ethics Committee of the Agricultural Sciences Campus of the Federal University of Parana and by the Authorization and Information on Biodiversity System from the Brazilian Institute of Environment and Natural Resources.

Pre-anesthetic management. Preanesthetic medication consisted of $9 \mathrm{mg}$ of meperidine (Dolosal ${ }^{\circledR} 50 \mathrm{mg} / \mathrm{ml}$, Cristália, São Paulo/SP) and $1.2 \mathrm{mg}$ of midazolam (Dormire ${ }^{\circledR} 5 \mathrm{mg} / \mathrm{ml}$, Cristália, São Paulo/SP). After premedication, blood samples were collected for a complete blood count using an automated blood cell counter (CC-550, Celm, Brazil). Renal and hepatic biochemical profile included creatinine, urea, alanine transaminase (ALT), aspartate transaminase (AST), alkaline phosphatase (ALP), gamma-glutamyl transferase (GGT), total protein (TP), and electrolytes (sodium, chloride and calcium) were determined by dry chemistry (Vitros ${ }^{\circledR}$ DT60II, Johnson \& Johnson Healthcare Systems, NY, USA) in serum sample.

Anesthesia. After weighing and cannulating the saphenous vein, monkeys were divided in propofol group (PRO) and tiletamine+zolazepam group (TZ). Randomization was performed by pulling a piece of paper from a bag with either group written on it. Weights, age, and other parameters were not determined for group assignment prior to capture and therefore randomized. The individuals responsible for initial capture and restraint were blinded to group divisions.

In TZ, $5 \mathrm{mg} / \mathrm{kg}$ of tiletamine+zolazepam $\left(\right.$ Zoletil $^{\circledR} 50$, Virbac, Brazil) was administered intravenously. Saline was infused at $10 \mathrm{ml} / \mathrm{kg} / \mathrm{h}$ with a peristaltic roller pump (LF2001, Lifemed, Brazil). In PRO, anesthetic induction was performed with using a syringe infusion pump (PSK-01, Nikkiso Co., Japan) at $2 \mathrm{mg} / \mathrm{kg} / \mathrm{min}$ of propofol (Propovan ${ }^{\circledR} 10 \mathrm{mg} / \mathrm{ml}$, Cristália, São Paulo/SP) until complete loss of palpebral reflexes. Saline solution was administered at a rate of $10 \mathrm{ml} / \mathrm{kg} / \mathrm{h}$ in contralateral saphenous vein. A laryngeal mask was placed, with oxygen flow of $1 \mathrm{~L} / \mathrm{min}$, administered through a Mapleson D Rees-Baraka non-rebreathing system, with spontaneous breathing. During anesthesia, animals were lying in dorsal recumbency.

A scale was used to determine anesthetic depth and determined the adjustment of the maintenance dose in order to provide similar depth of anesthesia. Scores from 1 to 4 were given based on the following scale: 1) poor muscle relaxation, intense palpebral reflex or voluntary movements of the tail, limbs or head; 2) no substantial changes in cardiopulmonary parameters (ranging less than $10 \%$ from the first measurement), complete relaxation, tongue can be exteriorized, no movements of the tail, limbs or head, slow palpebral reflex; 3) no substantial changes in cardiopulmonary parameters (ranging less than $10 \%$ from the first measurement), complete relaxation, tongue can 
be exteriorized, complete loss of palpebral reflexes and jaw muscle tone, no movements of the tail, limbs or head; 4) anesthetic plane is too deep, no reflexes or cardiopulmonary depression (at least two parameters $10 \%$ lower than the first measurement).

In TZ, when anesthetic depth was $1,2.5 \mathrm{mg} / \mathrm{kg}$ of tiletamine+zolazepam was administered IV. In PRO, an infusion of propofol $(0.4 \mathrm{mg} / \mathrm{kg} / \mathrm{min})$ was started the induction of anesthesia. In order to maintain an anesthetic score of 3 , the infusion rate was increased by $0.1 \mathrm{mg} / \mathrm{kg} / \mathrm{min}$ increments when the score was 2 , or by $0.2 \mathrm{mg} / \mathrm{kg} / \mathrm{min}$ when the score was 1 , and decreased by $0.1 \mathrm{mg} / \mathrm{kg} / \mathrm{min}$ when a score was 4 . Anesthesia was continued for 60 minutes and changes in propofol infusion rate, when necessary, were made every 5 minutes.

Plasma cortisol concentrations were measured by means of a commercial ELISA kit (DBC, Diagnostics Biochem, Canada) in the beginning ( 0 minute, immediately after induction of anesthesia) and end (60 minutes) of anesthesia. Cortisol was evaluated as the percentage of increase or decrease of the concentration. Every 5 minutes the animal had the following parameters evaluated: heart rate (HR), respiratory rate $(f R)$, non-invasive systolic (SAP), mean (MAP) and diastolic (DAP) arterial blood pressures, rectal temperature and arterial oxygen saturation of hemoglobin $\left(\mathrm{SpO}_{2}\right)$ using a veterinary portable multi-parameter monitor (MEC-1200Vet, Mindray Medical International, China). Non-invasive arterial blood pressures were measured by the oscillometric method with a number 2 sized cuff placed around the right arm. At the end of the 60 minutes' period, an arterial blood sample was collected from the femoral artery for blood gas analysis using a portable analyzer (EPOC Blood AnalysisTM, EPOCAL Inc., Canada). Parameters evaluated were: ionized calcium, bicarbonate $\left(\mathrm{HCO}_{3}\right)$, potassium, sodium, $\mathrm{pH}$, arterial partial pressures of carbon dioxide $\left(\mathrm{PaCO}_{2}\right)$ and oxygen $\left(\mathrm{PaO}_{2}\right)$, base excess (BE), glucose and lactate concentrations.

After 60 minutes of anesthesia, infusion was stopped, the laryngeal mask was removed and the animal was put on a table in dorsal recumbency, without any physical restraint.

Recovery. Anesthesia recovery times recorded were: time to first voluntary movement, time to voluntary lateral recumbency, time to voluntary ventral recumbency and time to normal ambulation. The subjects were transferred to the recovery cage immediately after ventral recumbency was observed. A score for the quality of anesthetic recovery was given based on the following: excellent - recumbency change with minimal ataxic movements, animal gets up in one or two attempts and it is able to ambulate with only slight ataxia; good - recumbency change with moderate ataxic movements, requiring more than two attempts to get up, ambulates with moderate ataxia and incoordenation; average - makes several attempts for recumbency change with severe ataxia, tries to get up but often falls down and finally walks with notable ataxia and incoordenation; poor - animal stays on the same recumbency for more than 30 minutes after the end of anesthesia, it is not responsive to stimuli and makes no effort to change recumbency, or has a very agitated recovery with severe ataxia and risk of injury.

Normality of data was verified by Kolmogorov-Smirnov test. Statistical analyses of parametric values were performed comparing groups using the t-test. The physiological parameters analyzed continuously during the anesthesia were tested using analysis of variance (ANOVA). When statistical differences were observed, mean values were compared by Tukey-Kramer post-hoc test. StatView 5.0.1 (SAS Institute Inc., NC, USA) was used. Quality of anesthetic recovery was analyzed by Fisher's exact test.

\section{RESULTS}

\section{Preanesthetic testing and preanesthetic medication}

Animals aged from four to 16 years old composed both groups. Each group was formed by two males and two females. The mean weight of PRO was $3.0 \pm 0.6$ and of TZ was $3.1 \pm 0.9 \mathrm{~kg}$. There were no statistical differences in ages or weights between groups. Hematologic and serum biochemistry values were similar in both groups (Table 1). Preanesthetic medication doses ranged from 2.3 to $4.6 \mathrm{mg} / \mathrm{kg}$ of meperidine and 0.30 to $0.61 \mathrm{mg} / \mathrm{kg}$ of midazolam. This protocol provided enough sedation to allow easy venous catheter placement with only light physical restraint.

\section{Propofol infusion rates}

The median time for induction of anesthesia in PRO was 177.5 seconds, ranging from 140 to 200 seconds, resulting in median induction dose of $5.9 \mathrm{mg} / \mathrm{kg}$, varying from 4.7 to $6.7 \mathrm{mg} / \mathrm{kg}$, during total induction period until complete loss of palpebral reflex. The mean infusion rate during anesthesia maintenance

Table 1. Hematological and biochemical values measured in capuchin monkeys (Sapajus apella) before anesthesia ( $\mathrm{n}=8$ ), mean \pm SD

\begin{tabular}{lccc}
\hline \multirow{2}{*}{ Parameter } & \multicolumn{2}{c}{ Group } & \multirow{2}{*}{$p$-value } \\
\cline { 2 - 3 } & PRO & TZ & 0.814 \\
Ht (\%) & $38.6 \pm 2.0$ & $39.4 \pm 7.1$ & 0.936 \\
$\mathrm{Hb} \mathrm{(g/dl)}$ & $12.5 \pm 0.6$ & $12.6 \pm 2.3$ & 0.836 \\
$\mathrm{TP}(\mathrm{g} / \mathrm{dl})$ & $7.5 \pm 0.5$ & $7.4 \pm 0.4$ & 0.454 \\
Ca (mmol/l) & $2.1 \pm 0.1$ & $2.12 \pm 0.08$ & 0.876 \\
Sodium (mmol/l) & $147.3 \pm 8.5$ & $148 \pm 3.5$ & 0.451 \\
Chloride (mmol/l) & $115 \pm 4.2$ & $117 \pm 2.5$ & 0.589 \\
Creatinine (mg/dl) & $0.91 \pm 0.15$ & $0.96 \pm 0.12$ & 0.102 \\
Urea (mg/dl) & $26 \pm 11.1$ & $45 \pm 16$ & 0.239 \\
AST (U/l) & $25.3 \pm 21.1$ & $56.5 \pm 42.8$ & 0.222 \\
ALT (U/l) & $40.3 \pm 26$ & $78.2 \pm 49.3$ & 0.401 \\
ALP (U/l) & $60.8 \pm 17.7$ & $72.5 \pm 19.1$ & 0.462 \\
GGT (U/l) & $89 \pm 66.6$ & $61.5 \pm 21.8$ &
\end{tabular}

PRO = propofol group, $\mathrm{TZ}=$ tiletamine+zolazepam group, $\mathrm{Ht}=$ hematocrit, $\mathrm{Hb}=$ hemoglobina, $\mathrm{TP}=$ total plasma protein, $\mathrm{Ca}=$ calcium, $\mathrm{AST}=$ aspartate aminotransferase, $\mathrm{ALT}=$ alanine aminotransferase, ALP = alkaline phosphatase, GGT= gamma-glutamyltransferase . 
was $0.37 \pm 0.11 \mathrm{mg} / \mathrm{kg} / \mathrm{min}$, varying during the one-hour period, according to the Figure 1.

\section{Tiletamine+zolazepam volume}

All animals were induced with $5 \mathrm{mg} / \mathrm{kg}$ tiletamine+zolazepam, IV. Two animals did not require any extra dose to maintain anesthetic level. The other two animals needed three and five extra doses of tiletamine+zolazepam $(2.5 \mathrm{mg} / \mathrm{kg})$, IV, to maintain the proposed anesthetic level.

\section{Physiological parameters}

Continuous physiological parameters evaluated are shown in Table 2. There were no statistically significant differences in HR between groups. In TZ, HR decreases significantly in the last 10 minutes of anesthesia when compared to the 5 minutes' assessment $(\mathrm{p}<0.05)$. $f \mathrm{R}$ was higher in TZ than in PRO, presenting statistical difference at 35,45 and 60 minutes $(p<0.05)$. No significant differences were found in arterial blood pressure and $\mathrm{SpO}_{2}$. The temperature decreased in both groups in relation to the beginning of anesthesia, presenting

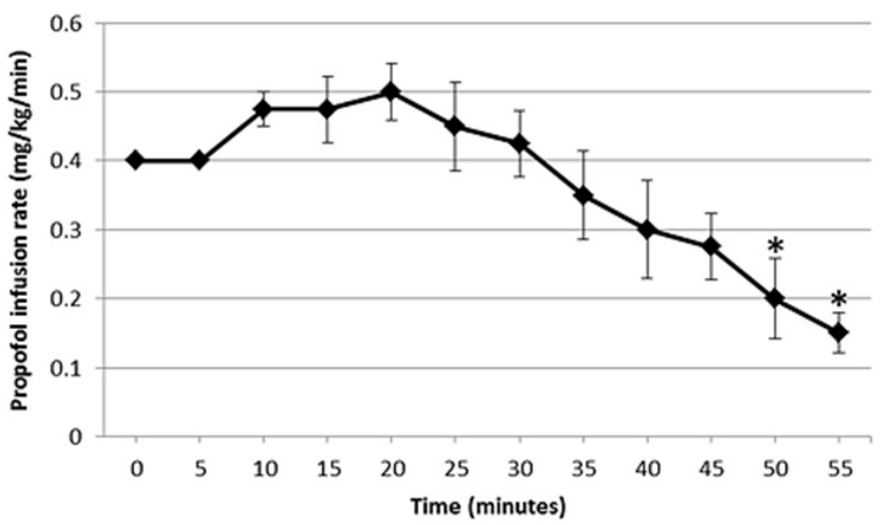

Fig.1. Propofol infusion rate variation $(n=4)$ during 1-hour of anesthesia in capuchin monkeys (Sapajus apella) premedicated with pethidine and midazolam. Mean \pm SD. faster decreases in PRO ( $p<0.05)$, but no significant difference between groups was noticed at the end of procedure.

\section{Arterial blood gas analysis and cortisol}

Both groups presented moderate academia at the end of anesthesia, as high base deficit, with clinically important higher values in TZ. Relatively high $\mathrm{PCO}_{2}$ and low $\mathrm{HCO}_{3}$ were found. There were $\mathrm{PaO}_{2}$ increased in both groups, however higher values are found in TZ group $(\mathrm{p}<0.05)$. Lactate was also high in both groups. All the values are presented in Table 3.

Different levels of cortisol were observed during the day, with the lowest values at the beginning of the morning $(65.22 \mu \mathrm{g} / \mathrm{dL})$, and the highest values at the middle of the day $(354.58 \mu \mathrm{g} / \mathrm{dL})$. In both groups, it was observed increasing in the cortisol level during the anesthesia, but no statistical difference was noticed in the mean percentage of raise in cortisol levels between TZ $(70.7 \pm 118.8)$ and PRO $(62.2 \pm 46)$.

\section{Recovering}

The anesthesia recovery evaluation is shown in Table 4. There was no statistical difference in time of first voluntary movements or posture repositioning. However, the times to postural recovery and normal ambulation were significantly faster in PRO $(\mathrm{p}<0.05)$. The anesthetic recovery quality was considered excellent in 4 out of 4 animals of PRO, and average in 2 out of 4 and poor in 2 out of 4 monkeys of TZ.

\section{DISCUSSION}

The use of animals in medical research follow guidelines to consideration and, if feasible, implementation of replacement, refinement and reduction methods. This means that, if possible, experiments have to be performed without animals (Replacement), with fewer animals (Reduction) and/or with less pain/distress for the animals (Refinement) (Russell \& Burch 1959, Luijk et al. 2013). Because of the easy intramuscular administration and effective chemical restraint, dissociative drugs as ketamine and tiletamine have been preferred in worldwide primate facilities. However, abnormal behavior,

Table 2. Physiologic variables recorded in capuchin monkeys (Sapajus apella) during 1-hour of propofol infusion (PR0, n=4) or tiletamine+zolazepam $(\mathrm{TZ}, \mathrm{n}=4)$ anesthesia, mean \pm SD

\begin{tabular}{|c|c|c|c|c|c|c|c|c|c|c|c|c|c|c|}
\hline \multirow{2}{*}{$\begin{array}{l}\text { Time } \\
\text { (min) }\end{array}$} & \multicolumn{2}{|c|}{$\begin{array}{c}\text { HR } \\
\text { (beats/minute) }\end{array}$} & \multicolumn{2}{|c|}{$\begin{array}{c}f \mathrm{R} \\
\text { (breaths/minute) }\end{array}$} & \multicolumn{2}{|c|}{$\begin{array}{c}\text { SAP } \\
(\mathrm{mmHg})\end{array}$} & \multicolumn{2}{|c|}{$\begin{array}{c}\text { MAP } \\
(\mathrm{mmHg})\end{array}$} & \multicolumn{2}{|c|}{$\begin{array}{c}\text { DAP } \\
(\mathrm{mmHg})\end{array}$} & \multicolumn{2}{|c|}{$\begin{array}{l}\mathrm{SpO}_{2} \\
(\%)\end{array}$} & \multicolumn{2}{|c|}{$\begin{array}{l}\text { Temp } \\
\left({ }^{\circ} \mathrm{C}\right)\end{array}$} \\
\hline & PRO & $\mathrm{TZ}$ & PRO & $\mathrm{TZ}$ & PRO & $\mathrm{TZ}$ & PRO & $\mathrm{TZ}$ & PRO & $\mathrm{TZ}$ & PRO & $\mathrm{TZ}$ & PRO & $\mathrm{TZ}$ \\
\hline 5 & $202 \pm 42$ & $236 \pm 37$ & $37 \pm 9$ & $40 \pm 5$ & $108 \pm 12$ & $121 \pm 9$ & $79 \pm 12$ & $96 \pm 9$ & $55 \pm 17$ & $73 \pm 11$ & $97 \pm 0$ & $97 \pm 1$ & $37.9 \pm 0.4$ & $38.6 \pm 0.3$ \\
\hline 10 & $168 \pm 43$ & $227 \pm 27$ & $30 \pm 8$ & $43 \pm 14$ & $109 \pm 12$ & $108 \pm 6$ & $78 \pm 13$ & $78 \pm 6$ & $54 \pm 16$ & $60 \pm 6$ & $98 \pm 2$ & $98 \pm 2$ & $37.4 \pm 0.5$ & $38.4 \pm 0.2^{*}$ \\
\hline 15 & $172 \pm 36$ & $221 \pm 23$ & $33 \pm 10$ & $35 \pm 10$ & $103 \pm 11$ & $105 \pm 3$ & $78 \pm 10$ & $77 \pm 8$ & $50 \pm 15$ & $57 \pm 9$ & $99 \pm 2$ & $97 \pm 2$ & $37.2 \pm 0.3$ & $38.1 \pm 0.2^{*}$ \\
\hline 20 & $162 \pm 41$ & $211 \pm 19$ & $27 \pm 8$ & $41 \pm 11 \S$ & $104 \pm 7$ & $107 \pm 5$ & $74 \pm 11$ & $81 \pm 9$ & $54 \pm 15$ & $58 \pm 11$ & $98 \pm 2$ & $99 \pm 1$ & $36.9 \pm 0.3$ & $37.7 \pm 0.3$ \\
\hline 25 & $164 \pm 36$ & $207 \pm 17$ & $31 \pm 5$ & $39 \pm 11$ & $102 \pm 10$ & $110 \pm 8$ & $74 \pm 11$ & $83 \pm 10$ & $54 \pm 10$ & $61 \pm 12$ & $98 \pm 2$ & $98 \pm 2$ & $36.6 \pm 0.2 \#$ & $37.4 \pm 0.3$ \\
\hline 30 & $174 \pm 23$ & $202 \pm 14$ & $27 \pm 9$ & $36 \pm 17$ & $101 \pm 10$ & $106 \pm 9$ & $79 \pm 10$ & $80 \pm 10$ & $54 \pm 8$ & $62 \pm 11$ & $98 \pm 2$ & $97 \pm 2$ & $36.3 \pm 0.2 \#$ & $37.1 \pm 0.3$ \\
\hline 35 & $171 \pm 26$ & $197 \pm 8$ & $26 \pm 4$ & $36 \pm 3^{*}$ & $103 \pm 10$ & $108 \pm 10$ & $78 \pm 8$ & $81 \pm 10$ & $50 \pm 11$ & $63 \pm 10$ & $99 \pm 2$ & $97 \pm 2$ & $36.1 \pm 0.2 \#$ & $36.8 \pm 0.4$ \\
\hline 40 & $169 \pm 29$ & $196 \pm 9$ & $28 \pm 5$ & $37 \pm 11$ & $100 \pm 9$ & $107 \pm 9$ & $77 \pm 8$ & $79 \pm 8$ & $58 \pm 9$ & $64 \pm 11$ & $99 \pm 2$ & $96 \pm 2$ & $35.8 \pm 0.2 \#$ & $36.4 \pm 0.3 \#$ \\
\hline 45 & $160 \pm 28$ & $192 \pm 6$ & $28 \pm 2$ & $45 \pm 13^{*}$ & $101 \pm 10$ & $106 \pm 7$ & $76 \pm 9$ & $78 \pm 5$ & $52 \pm 12$ & $61 \pm 7$ & $99 \pm 2$ & $96 \pm 2$ & $35.6 \pm 0.2 \#$ & $36.2 \pm 0.3 \#$ \\
\hline 50 & $158 \pm 26$ & $184 \pm 6 \#$ & $24 \pm 9$ & $41 \pm 18$ & $103 \pm 8$ & $106 \pm 8$ & $75 \pm 8$ & $79 \pm 9$ & $53 \pm 6$ & $59 \pm 8$ & $99 \pm 2$ & $97 \pm 2$ & $35.5 \pm 0.2 \#$ & $35.9 \pm 0.4 \#$ \\
\hline 55 & $163 \pm 30$ & $182 \pm 9 \#$ & $28 \pm 5$ & $35 \pm 17$ & $104 \pm 3$ & $107 \pm 9$ & $76 \pm 7$ & $82 \pm 10$ & $56 \pm 12$ & $59 \pm 16$ & $99 \pm 2$ & $98 \pm 1$ & $35.2 \pm 0.2 \#$ & $35.8 \pm 0.4 \#$ \\
\hline 60 & $152 \pm 33$ & $177 \pm 11 \#$ & $26 \pm 3$ & $38 \pm 7^{*}$ & $109 \pm 5$ & $120 \pm 17$ & $81 \pm 4$ & $88 \pm 14$ & $53 \pm 11$ & $66 \pm 9$ & $99 \pm 2$ & $97 \pm 2$ & $35.1 \pm 0.2 \#$ & $35.5 \pm 0.3 \#$ \\
\hline
\end{tabular}

* Difference between groups $p<0.05$, \# Difference inside the group (in relation to baseline at 5 minutes) $\mathrm{p}<0.05$; HR $=$ heart rate, $f \mathrm{R}=$ respiratory rate, $\mathrm{SpO}_{2}=$ hemoglobin oxygen saturation, Temp = temperature, $\mathrm{SAP}=$ systolic arterial pressure, $\mathrm{MAP}=$ mean arterial pressure, $\mathrm{DAP}=$ diastolic arterial pressure. 
Table 3. Arterial blood gas values and serum electrolytes in capuchin monkeys (Sapajus apella) at the end of 1- hour of propofol (PRO, $n=4)$ or tiletamine+zolazepam $(T Z, n=4)$ anesthesia, mean \pm SD

\begin{tabular}{|c|c|c|c|}
\hline \multirow{2}{*}{ Parameter } & \multicolumn{2}{|c|}{ Group } & \multirow{2}{*}{$p$-value } \\
\hline & PRO & $\mathrm{TZ}$ & \\
\hline $\mathrm{pH}$ & $7.238 \pm 0.062$ & $7.191 \pm 0.020$ & 0.195 \\
\hline $\mathrm{PaCO}_{2}(\mathrm{mmHg})$ & $47.7 \pm 9.7$ & $48.0 \pm 3.5$ & 0.963 \\
\hline $\mathrm{PaO}_{2}(\mathrm{mmHg})$ & $476 \pm 64$ & $598 \pm 47^{*}$ & 0.022 \\
\hline $\mathrm{HCO}_{3}\left(\mathrm{mmol} \mathrm{L}^{-1}\right)$ & $19.4 \pm 3.3$ & $17.7 \pm 1.1$ & 0.361 \\
\hline $\mathrm{BE}\left(\mathrm{mmol} \mathrm{L}^{-1}\right)$ & $-6.9 \pm 3.2$ & $-9.1 \pm 1.0$ & 0.227 \\
\hline Potassium (mmol L-1) & $4.6 \pm 1.2$ & $5.2 \pm 0.6$ & 0.351 \\
\hline Ionized Calcium $\left(\mathrm{mmol} \mathrm{L}^{-1}\right)$ & $1.8 \pm 0.2$ & $2.0 \pm 0.1$ & 0.235 \\
\hline Total Serum Calcium $\left(\mathrm{mmol} \mathrm{L}^{-1}\right)$ & $2.1 \pm 0.1$ & $2.1 \pm 0.1$ & 0.550 \\
\hline Glucose $\left(\mathrm{mg} \mathrm{dL}^{-1}\right)$ & $85 \pm 17$ & $81 \pm 16$ & 0.786 \\
\hline Lactate $\left(\mathrm{mg} \mathrm{dL}^{-1}\right)$ & $5.4 \pm 0.1$ & $6.9 \pm 2.5$ & 0.252 \\
\hline
\end{tabular}

$\mathrm{PaCO}_{2}=$ arterial partial pressure of carbon dioxide, $\mathrm{PaO}_{2}=$ arterial partial pressure of oxygen, $\mathrm{HCO}_{3}=$ bicarbonate, $\mathrm{BE}=$ base excess, SaO ${ }_{2}=$ oxygen saturation; * Difference between groups $p<0.05$.

Table 4. Times (minutes) to stages of recovery from 1-hour of propofol (PRO, n=4) or tiletamine+zolazepam (TZ, n=4) anesthesia in capuchin monkeys (Sapajus apella), mean \pm SD

\begin{tabular}{lccc}
\hline \multirow{2}{*}{ Recovery times (min) } & \multicolumn{2}{c}{ Group } & \multirow{2}{*}{$p$-value } \\
\cline { 2 - 3 } & PRO & TZ & \\
\hline $\begin{array}{l}\text { Time to first voluntary } \\
\text { movement }\end{array}$ & $9.2 \pm 5.6$ & $18.5 \pm 9.2$ & 0.277 \\
$\begin{array}{l}\text { Time to lateral } \\
\text { recumbency }\end{array}$ & $19.2 \pm 16.5$ & $50.7 \pm 32.9$ & 0.153 \\
$\begin{array}{l}\text { Time to ventral } \\
\text { recumbency }\end{array}$ & $43 \pm 21.4$ & $244.0 \pm 97.0^{*}$ & 0.009 \\
$\begin{array}{l}\text { Time to normal } \\
\text { and }\end{array}$ & $93 \pm 27.1$ & $493.7 \pm 47.8^{*}$ & $<0.001$
\end{tabular}

ambulation

* Difference between groups $p<0.05$.

which may progress to delirium, may occur during emergence from dissociative anesthesia (Lin 2007). Depression of the inferior colliculus and medial geniculate nucleus leading to misperception of auditory and visual stimuli may be responsible for this reaction (White et al. 1982). Emergence reactions are characterized by ataxia, increased motor activity, hyperreflexia, sensitivity to touch, and sometimes violent recovery (Wright 1982). These reactions usually disappear within several hours without recurrence (Amend et al. 1972). Because of this, refinement of anesthesia, excluding use of dissociative anesthetics to promote unconsciousness, needs to be discussed.

On the other hand, the greatest advantage in the use of propofol is the quality of anesthesia recovery. It propitiates smooth return to consciousness, besides that, it presents high clearance rate, with fast metabolism by the hepatic and extra hepatic routes, with no active metabolites described, properties that favor a rapid recovery from anesthesia, depending on the duration of infusion (Aguiar 2010, Jimenez et al. 2012). Recovery was remarkably faster and more pleasant with continuous infusion of propofol in these capuchin monkeys. All specimens anesthetized with propofol were able to get up in first attempt with only slight ataxia during early ambulation.
It was considered complete recovery when the animal returns to normal ambulation, which is the moment when it is possible to the monkey to go back to its group without any social problems. Monkeys that received dissociative anesthesia spent at least seven hours to return to original facilities after anesthesia, and their recovery was characterized by very agitated awakening with severe ataxia and risk of injury in two animals and by several attempts to get up, but often falling and notable ataxia and incoordination in other two. Compared to dissociative anesthesia, it is expected less abnormal events in recovery with propofol, after anesthetic procedures and faster return of animals to their cages.

Cortisol, the principal glucocorticoid in primates, can be an important indicator of pathophysiological processes, and the cortisol response to an event is often considered a useful indicator of stress (Bentson et al. 2003). High absolute basal levels of cortisol characterize New World primate species. Moreover, capuchin monkeys, as other primates, have shown to present increased cortisol levels in response to handling (Dettmer et al. 1996). Cortisol is capable of increasing in response to capture and chair restraint and turnover rate of cortisol is extremely high (Brown et al. 1970). It may be secreted as a direct response to an environmental or social stress and it may also be considered an enhancer for rapid physical response, as it mobilizes circulating glucose to provide readily available energy for muscular activity (Sapolsky 1992, Lynch et al. 2002).

Since it is known that cortisol levels change during the day (Lynch et al. 2002), it is erroneous to compare serum levels among animals that were anesthetized in different periods. We only used the variation between the start and the end of anesthesia. However, blood sample was collected before recovery and this method did not permit we observe the impact of that in cortisol response.

Both experimental groups presented similar conditions of weight, health and sex. Pre-anesthetic testing was performed just to assure health status, and all the results are under normal reference range for the species (Wirz \& Riviello 2008). Premedication with meperidine and midazolam permitted 
satisfactory manipulation and instrumentation, making the venous cannulation easier.

The $2 \mathrm{mg} / \mathrm{kg} / \mathrm{min}$ rate of propofol for induction was able to abolish palpebral reflex between 140 and 200 seconds. Administration of induction doses of propofol over 2 minutes provides a reasonable rate and improved titration to effect, yet avoids excessively high arterial concentrations and cardiovascular and ventilatory depressive effects (Ludbrook et al. 1998). The maintenance infusion rate of propofol had to be lightly increased until 20 minutes of anesthesia, probably the moment of compartmental equilibrium, and then reduced, reaching statistically significant difference in 50 and 55 minutes. This behavior was different from the observed in feline night monkeys, where infusion rates above $0.4 \mathrm{mg} / \mathrm{kg} / \mathrm{min}$ of propofol were necessary until the end of anesthesia (Galante et al. 2014). A variable-rate infusion, in which the rate is altered according to the current or anticipated stimulus, is more useful clinically than a constant rate infusion (Shafer et al. 1988). Nevertheless, in case of total intravenous anesthesia to be performed using a constant rate infusion, rates lower than $0.4 \mathrm{mg} / \mathrm{kg} / \mathrm{min}$ will be enough after 20 minutes to capuchin monkeys.

Tiletamine-zolazepam is known to cause cardiovascular stimulation (Hall et al. 2001), as long as the adrenergic system is intact (Paddleford 1999). The clinically, but not statistically, high HR in TZ group, observed in beginning of anesthesia, is attributed to enhanced sympathetic tone and perhaps decreased vagal tone (Thurmon et al. 1996, Saha et al. 2007). HR decreased progressively due to the consumption of catecholamines. Otherwise, even presenting the highest HR in the first evaluation in PRO, probably because of the stress caused by initial manipulation, HR in PRO remained around a constant and physiological rate.

Parasympathetic activity promoted by propofol can decrease arterial blood pressure. That has been attributed to a decrease in systemic vascular resistance or in cardiac output caused by a combination of venous and arterial vasodilation, impaired baroreflex mechanisms, and depression of myocardial contractility (Kanaya et al. 2003, Win et al. 2005). However, all these effects seem to be dose-dependent (Zausig et al. 2009), and using titrated continuous rate infusion we did not observed any statistical difference in arterial blood pressure.

Minor respiratory alteration occurred either with propofol or tiletamine-zolazepam anesthesia. In the present study, arterial blood gas analysis was not performed in the beginning of anesthesia, but slight high values in $\mathrm{PCO}_{2}$ in the end of the procedure were detected. This is an expected alteration in a long-term anesthesia with spontaneous breathing and stronger alterations are reported with propofol and dissociative anesthesia with this condition (Booker Junior et al. 1982, Hou et al. 1992). As anesthesia with propofol is likely to be accompanied by respiratory depression and hypotension, further studies with a larger number of animals could show alterations that were not reported in this research.

Capuchin monkeys have social behavior and are caged in groups but, even being a recurrent procedure, capture of the animals for drug administration was slow and slightly stressful. High lactic acid production caused by intense muscular activity during capture, indicated by elevated lactate levels, induced metabolic acidosis. Low $\mathrm{pH}$ and base excess illustrate metabolic acidosis, which are common findings in physically restrained primates (Bush et al. 1977, Galante et al. 2014). As other physiological parameters did not show important modifications during anesthesia to justify the observed blood gas alterations, we are assuming that this metabolic acidosis had happened due to stressful capture.

\section{CONCLUSIONS}

Propofol induced complete unconsciousness in capuchin monkey after $173.7 \pm 26.8$ seconds at $2 \mathrm{mg} / \mathrm{kg} / \mathrm{min}$ infusion rate and the mean rate to maintain a 60 minutes anesthesia was $0.37 \pm 0.11 \mathrm{mg} / \mathrm{kg} / \mathrm{min}$, despite the necessity of titrate this rate during the procedure.

Compared to the well-known tiletamine-zolazepam protocol, closed physiological alterations were observed, but faster and smoother anesthetic recovery and minor post-anesthetic unpleasant events are expected with propofol anesthesia.

Acknowledgments.- The authors express their gratitude to Centro Nacional de Primatas and Maristela Toledo for the laboratory technical assistance.

Conflict of interest statement.- The authors declare that they have no conflict of interest.

\section{REFERENCES}

Aguiar A.A. 2010. Anestesia intravenosa total, p.275-297. In: Fantoni D.T \& Cortopassi S.R.G (Eds), Anestesia em Cães e Gatos. $2^{\underline{a}}$ ed. Roca, São Paulo.

Amend J.F., Klavano P.A. \& Stone E.C. 1972. Premedication with xylazine to eliminate muscular hypertonicity in cats during ketamine anesthesia. Vet. Med. Small Anim. Clin. 67(12):1305-1307. <PMid:4486539>

Bentson K.L., Capitanio J.P. \& Mendoza S.P. 2003. Cortisol responses to immobilization with Telazol or ketamine in baboons (Papio cynocephalus) anubis) and rhesus macaques (Macaca mulatta). J. Med. Primatol. 32(3):148-160. <http://dx.doi.org/10.1034/j.1600-0684.2003.00018. $\mathrm{x}><$ PMid:12823625>

Booker Junior J.L., Erickson H.H. \& Fitzpatrick E.L. 1982. Cardiodynamics in the rhesus macaque during dissociative anesthesia. Am. J. Vet. Res. 43(4):671-675. <PMid:7073088>

Brown G.M., Grota L.J., Penney D.P. \& Reichlin S. 1970. Pituitary-adrenal function in the squirrel monkey. Endocrinology 86(3):519-529. <http:// dx.doi.org/10.1210/endo-86-3-519><PMid:4312110>

Bufalari A., Nilsson L.E., Short C.E. \& Giannoni C. 1995. A comparative study of neurologically-equivalent propofol anaesthetic combinations in the dog. J. Vet. Anaesth. 22(1):19-24. <http://dx.doi.org/10.1111/j.1467-2995.1995. tb00137.x>

Bush M., Custer R., Smeller J. \& Bush L.M. 1977. Physiologic measures of nonhuman primates during physical restraint and chemical immobilization. J. Am. Vet. Med. Assoc. 171(9):866-869. <PMid:21868>

Camu F., Lauwers M. \& Vanlersberghe C. 2001. Anestesia venosa total, p.370386. In: White P.F (Ed), Tratado de Anestesia Venosa. Artmed, Porto Alegre.

Court M.H., Duan S.X., Hesse L.M, Venkatakrishnan K. \& Greenblatt D.J. 2001. Cytochrome P-450 2B6 is responsible for interindividual variability of propofol hydroxylation by human liver microsomes. Anesthesiology 94(1):110-119.

Dettmer E.L., Phillips K.A., Rager D.R., Bernstein I.S. \& Fragaszy D.M. 1996. Behavioral and cortisol responses to repeated capture and venipuncture in Cebus apella. Am. J. Primatol. 38(4):357-362. <http://dx.doi.org/10.1002/ (SICI)1098-2345(1996)38:4<357::AID-AJP6>3.0.CO;2-Y>

Domingues S.F.S., Ferreira H.S., Muniz J.A.P.C., Lima A.K.F., Ohashi O.M., Figueiredo J.R. \& Silva L.D.M. 2003. Mechanical isolation of capuchin monkey (Cebus 
apella) preantral ovarian follicles. Arq. Bras. Med. Vet. Zootec. 55(3):301308. <http://dx.doi.org/10.1590/S0102-09352003000300009>

Galante R., Muniz J.A.P.C., Castro P.H.G, Amora Jr. D.S., Gris V.N., Carvalho E.R. \& Vilani R.G.D'O.C. 2014. Continuous infusion of propofol or intermittent bolus of tiletamine-zolazepam in feline night monkeys (Aotus infulatus). J. Med. Primatol. 43(2014):22-30.

Ganem E.M., Fukushima F.B., Silva D.S., Nakamura G., Castiglia Y.M. \& Vianna P.T. 2002. Efficacy of propofol and propofol plus dexamethasone in controlling postoperative nausea and vomiting of gynecologic laparoscopy. Revta Bras. Anestesiol. 52(4):394-401. <PMid:19479103>

Hall L.W., Clarke K.W. \& Trim C.M. 2001. Veterinary Anaesthesia. 10th ed. W.B. Saunders Company, London. 576p.

Hou W.Y., Huang F.Y., Sun W.Z., Susetio L., Chen C.L., Liang H.C. \& Huang C.H. 1992. The effect of total intravenous propofol on spontaneous respiration during anesthesia for minor surgery. Ma Zui Xue Za Zhi 30(1):7-11. <PMid:1608323>

Jiménez C.P., Mathis A., Mora S.S., Brodbelt D. \& Alibhai H. 2012. Evaluation of the quality of the recovery after administration of propofol or alfaxalone for induction of anaesthesia in dogs anaesthetized for magnetic resonance imaging. Vet. Anaesth. Analg. 39(2):151-159. <http://dx.doi. org/10.1111/j.1467-2995.2011.00678.x><PMid:22117934>

Kanaya N., Hirata N., Kurosawa S., Nakayama M. \& Namiki A. 2003. Differential effects of propofol and sevoflurane on heart rate variability. Anesthesiology 98(1):34-40.<http://dx.doi.org/10.1097/00000542-200301000-00009> $<$ PMid:12502976>

Kotani Y., Shimazawa M., Yoshimura S., Iwama T. \& Hara H. 2008. The experimental and clinical pharmacology of propofol, an anesthetic agent with neuroprotective properties. CNS Neurosci. Therap. 14(2):95-106. <http://dx.doi.org/10.1111/j.1527-3458.2008.00043.x><PMid:18482023>

Lin H.C. 2007. Dissociative anesthetics, p.301-354. In: Tranquilli W.J., Thurmon J.C. \& Grimm K.A. (Eds), Lumb \& Jones' Veterinary Anesthesia and Analgesia. 3rd ed. Blackwell Publishing, Ames.

Ludbrook G.L., Upton R.N., Grant C. \& Martinez A. 1998. The effect of rate of administration on brain concentrations of propofol in sheep. Anesth. Analg. 86(6):1301-1306. <PMid:9620524>

Luijk J., Cuijpers Y., van der Vaart L., De Roo T.C., Leenaars M. \& RitskesHoitinga M. 2013. Assessing the application of the 3Rs: a survey among animal welfare officers in The Netherlands. Lab. Anim. 47(3):210-219.

Lynch J.W., Ziegler T.E. \& Strier K.B. 2002. Individual and seasonal variation in fecal testosterone and cortisol levels of wild male tufted capuchin monkeys, Cebus apella nigritus. Hormones Behavior 41(3):275-287. <http://dx.doi. org/10.1006/hbeh.2002.1772 > <PMid:11971661>

Matot I., Neely C.F, Katz R.Y. \& Neufeld G.R.1993. Pulmonary uptake of propofol in cats: effect of fentanyl and halothane. Anesthesiology 78(6):1157-1165.

Olberg R.A. 2007. Monkeys and gibbons, p.375-386. In: West G., Heard D. \& Caulkett N. (Eds), Zoo Animal \& Wildlife Immobilization and Anesthesia.
Blackwell Publishing, Ames. <http://dx.doi.org/10.1002/9780470376478. $\operatorname{ch} 32>$.

Paddleford R.R. 1999. Manual of Small Animal Anesthesia. 2nd ed. W.B. Saunders, Philadelphia.

Paula D.P., Nunes N., Nishimori C.T.D., Lopes P.C.F., Carareto R. \& Santos P.S.P. 2012. Efeitos da infusão contínua de propofol ou etomidato sobre variáveis intracranianas em cães. Arq. Bras. Med. Vet. Zootec. 62(2):302-308. <http:// dx.doi.org/10.1590/S0102-09352010000200009>

Russell W.M.S. \& Burch R.L. 1959. The Principles of Humane Experimental Technique. Methuen, London. 238p.

Saha D.C., Saha A.C., Malik G., Astiz M.E. \& Rackow E.C. 2007. Comparison of cardiovascular effects of tiletamine-zolazepam, pentobarbital, and ketamine-xylazine in male rats. J. Am. Assoc. Lab. Anim. Sci. 46(2):74-80. $<$ PMid:17343357>

Sapolsky R.M. 1992. Cortisol concentrations and the social significance of rank instability among wild baboons. Psychoneuroendocrinology 17(6):701-709. <http://dx.doi.org/10.1016/0306-4530(92)90029-7><PMid:1287688>

Shafer A., Doze V.A., Shafer S.L. \& White P.F. 1988. Pharmacokinetics and pharmacodynamics of propofol infusions during general anesthesia. Anesthesiology 69(3):348-356. <http://dx.doi.org/10.1097/00000542198809000-00011><PMid:3261954>

Smith I., White P.F., Nathanson M. \& Gouldson R. 1994. Propofol: an update on its clinical use. Anesthesiology 81(4):1005-1043. <http://dx.doi. org/10.1097/00000542-199410000-00028><PMid:7943815>

Thurmon J.C., Tranquilli W.J. \& Benson G.J. 1996. Preanesthetics and anesthetic adjuncts, p.183-209. In: Tranquilli W.J., Thurmon J.C. \& Grimm K.A. (Eds), Lumb and Jones' Veterinary Anesthesia. 3rd ed. Lea and Feabiger, Philadelphia.

Vilani R.G.D.C. 2009. Anestesia em primatas não-humanos, p.297-310. In: Kindlovits A. \& Kindlovits L.M. (Eds), Clínica e Terapêutica em Primatas Neotropicais. 2 $2^{\underline{a}}$ ed. L.F. Livros, Rio de Janeiro.

White P.F., Way W.L. \& Trevor A.J. 1982. Ketamine-its pharmacology and therapeutic uses. Anesthesiology 56(2):119-136. <http://dx.doi. org/10.1097/00000542-198202000-00007><PMid:6892475>

Win N.N., Fukayama H., Kohase H. \& Umino M. 2005. The different effects of intravenous propofol and midazolam sedation on hemodynamic and heart rate variability. Anesth. Analg. 101(1):97-102. <http://dx.doi. org/10.1213/01.ANE.0000156204.89879.5C><PMid:15976213>

Wirz A. \& Riviello M.C. 2008. Reproductive parameters of a captive colony of capuchin monkeys (Cebus apella). Primates 49(4):265-270.

Wright M. 1982. Pharmacologic effects of ketamine and its use in veterinary medicine. J. Am. Vet. Med. Assoc. 180(12):1462-1471. <PMid:6124527>

Zausig Y.A., Busse H., Lunz D., Sinner B., Zink W. \& Graf B.M. 2009. Cardiac effects of induction agents in the septic rat heart. Critical Care 13(5):1-8. <http://dx.doi.org/10.1186/cc8038> <PMid:19737388> 